BNĹ 50939

\title{
NORMAL INCIDENT SOLAR RADIATION MEASUREMENTS AT UPTON, NEW YORK
}

\author{
J.G. COTTINGHAM
}

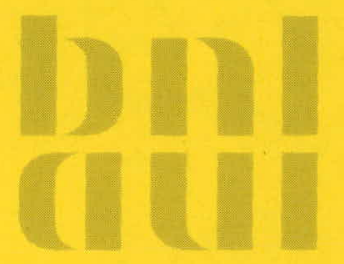

October 24, 1978

\section{ACCELERATOR DEPARTMENT}

BROOKHAVEN NATIONAL LABORATORY ASSOCIATED UNIVERSITIES, INC. UNDER CONTRACT NO. EY-76-C-02-0016 WITH THE UNITED STATES DEPARTMENT OF ENERGY 


\section{DISCLAIMER}

This report was prepared as an account of work sponsored by an agency of the United States Government. Neither the United States Government nor any agency Thereof, nor any of their employees, makes any warranty, express or implied, or assumes any legal liability or responsibility for the accuracy, completeness, or usefulness of any information, apparatus, product, or process disclosed, or represents that its use would not infringe privately owned rights. Reference herein to any specific commercial product, process, or service by trade name, trademark, manufacturer, or otherwise does not necessarily constitute or imply its endorsement, recommendation, or favoring by the United States Government or any agency thereof. The views and opinions of authors expressed herein do not necessarily state or reflect those of the United States Government or any agency thereof. 


\section{DISCLAIMER}

Portions of this document may be illegible in electronic image products. Images are produced from the best available original document. 


\title{
NORMAL INCIDENT SOLAR RADIATION MEASUREMENTS AT UPTON, NEW YORK
}

\author{
J.G. COTINGHAM
}

October 24, 1978

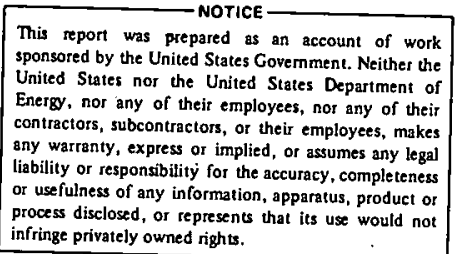

\section{ACCELERATOR DEPARTMENT}

BROOKHAVEN NATIONAL. LABORATORY UPTON, NEW YORK 11973 



\section{ABSTRACT}

Normal incident solar energy measurements made at Upton, L.I., New York are reported and analyzed relative to the total energy received on a horizontal surface. A new method for computing normal incident solar radiation is developed and used to study long term variations in this energy source at Upton and to estimate average values for other east coast locations. 
The northeastern part of the United States is not the sunniest part of the country. And for this reason much of the solar energy research and demonstration is planned and conducted in the southwest. This is particularly true for energy concentrating type systems. These system collect energy only from the normal incident beam and it is this energy form that is most effected by atmosphere scattering. Collecting systems that respond to scattered light recollect some of the energy scattered from the direct beam.

Nevertheless concentrating type systems must not be eliminated from the Northeast region of the country since their high temperature output is essential to certain application. Most cooling, mechanical and electrical generating systems fall into this application set. The northeast is also unique in that this region of the country has an in-place steam utilization technology with many building systems completely motivated by steam for both heating and cooling purposes.

As part of the heliostat development project at Brookhaven National Laboratory normal incident solar radiation measurements were made at Upton, N.Y. which is located on Long Island 70 miles east of New York City. For this purpose an Eppley Normal Incident Pyrheliometer was mounted on the roof of the Atmospheric Science Building and operated by that group. Daily data was digitally recorded and processed by $R$. M. Brown. This data together with pyranometer reading giving the radiations received on a horizontal surface was processed.by $D$. White and $C$. Henderson under the able direction of J. Tichler. This report is based on data collected over the 13 month period from June 1977 to June 1978.

In order that total incident energy. be reported missing and erroneous data must be restored. Missing data results principally from two causes, failure in the recording equipment and tracking errors.

Mr. Paul Vosganian joined our staff in the summer of 1978 and addressed this data restoration problem. The normal incident readings were plotted versus the pyranometer reading for each month. Plots thus made display a general smooth relationship. Data points far removed from this smooth curve were considered erroneous and were eliminated. The remaining data was fit with a curve of the form $\mathrm{y}=a x^{\mathrm{n}}$ using a least squares method. Missing and erroneous pyraheliometer readings were replaced by values read from the curve fit, if pyranometer readings were available. 
If no readings were available, the pyraheliometer value was assumed to be equal to the average for the month. Table I summarizes these results. For comparison long term values for solar radiation measured on a horizontal surface copied from reference 1 are also included in Table 1.

It is clear from examining Table 1 that the period over which these measurements were made was not typical, and in general contain less solar insolation than reported as average for this location. Figure 1 plots this monthly average atmospheric transmission coefficient $\bar{K}_{\mathrm{H}}$, the daily average ratio of solar energy received on a horizontal surface to that outside the atmosphere, for the long term Lui and Jordan data and for the months recently measured. The 1977 time period is notably below the average. Figure 2 shows the horizontal insolation as reported by additional referencesl,2,3.

Figure 2 clearly shows changes in the averages measured for different time periods. It is believed that the Lui and Jordan work ${ }^{1}$ is based in part on data from the 1950 time period and is therefore higher than indiated by later measurement.

In an effort to relate this brief set of normal incident solar insolation measurement to that of other time periods two parameters were defined, $\overline{\mathrm{K}}_{\mathrm{H}}$, defined as before and $\bar{K}_{\perp}$ the same ratio measured at normal incidence.

These parameters were computed for each day for which good data was available and grouped into small bin and averaged. The resulting data set was fit with a third order polynomial. The result is shown in Figure $3 \mathrm{a}$ and the equation for the fit is:

$$
\overline{\mathrm{K}}_{\perp}=.5548\left(\overline{\mathrm{K}}_{\mathrm{H}}\right)^{3}+.9949\left(\overline{\mathrm{K}}_{\mathrm{H}}\right)^{2}-. .4218 \overline{\mathrm{K}}_{\mathrm{H}}+.0526
$$

Figure $3 b$ shows the daily data superimposed on this polynomial.

This curve fit appears.to be seasonally invariant. Data from widely spaced months are shown plotted superimposed with the curve of the polynomial in Figures 4 through 7 and no seasonal effects are evident. Time will test this invarient assumption.

If the relationship between these two atmospheric transmissions coefficients is seasonally invarient, it is reasonable to expect it to be invarient over the long term, since it is in major part a comparison between two methods for measuring the transmission of solar energy through the atmosphere. 
Table 1

Solar Radiation Upton, N.Y. (BTU/ft ${ }^{2}$ )

\begin{tabular}{|c|c|c|c|}
\hline $\begin{array}{l}\text { Long Term } \\
\text { Lui-Jordan }\end{array}$ & $\begin{array}{r}\text { Measur } \\
\text { Daily Av }\end{array}$ & $\begin{array}{l}\text { d } \\
\text { rage }\end{array}$ & $\begin{array}{c}\text { Monthly } \\
\text { Total } \\
\end{array}$ \\
\hline 2159.0 & June ' 77 & $1856 . C$ & 55680. \\
\hline 2044.6 & July $' 77$ & 2014.8 & 62459. \\
\hline 1789.6 & Aug 177 & 1467.5 & 45493. \\
\hline 1472.7 & Sept 177 & 1156.0 & 34680 . \\
\hline 1102.6 & Oct $\cdot 77$ & 820.4 & 25432 . \\
\hline 686.7 & Nov 177 & 473.1 & 14193. \\
\hline 551.3 & Dec $' 77$ & 439.0 & $i 3609$ \\
\hline 583.0 & Jan 18 & 547.6 & 16976 \\
\hline 872.7 & Feb 178 & 993.5 & 27818 \\
\hline 1280.4 & Mar 178 & 1239.1 & 38412 \\
\hline 1609.9 & Apr 178 & 1526.9 & 45807 \\
\hline 1891.5 & May ' 78 & 1506.7 & 46708 \\
\hline 2159.0 & June ' 78 & 2067.1 & 62013 \\
\hline Yearly Total & $7 / 77-7 / 68$ & & $34 \times 10^{5}$ \\
\hline
\end{tabular}

Normal Incident Solar Radiation

$\begin{array}{cc}\begin{array}{c}\text { Measured } \\ \text { Daily Average }\end{array} & \text { Monthly } \\ \text { Total }\end{array}$

June '77 $1270.0 \quad 38100$

July '77 $1626.0 \quad 50406$

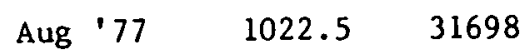

Sept $177 \quad 914.6 \quad 27438$

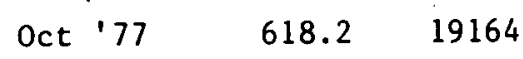

$\begin{array}{lll}\text { Nov } 77 & 313.4 & 9402\end{array}$

Dec $177 \quad 649.0 \quad 20119$

Jan' $77 \quad 800.0 \quad 24800$

Feb ' $78 \quad 1517.2 \quad 42482$

Mar $78 \quad 1241.0 \quad 38471$

Apr $78 \quad 1279.5 \quad 38385$

May $78 \quad 1148.0 \quad 35588$

June '78. $1624.4 \quad 48732$

Yearly Total $7 / 77-6 / 783.87 \times 10^{5}$ 
With the assumptions of a fixed relationship between horizontally and normal incident measured transmission coefficient methods for estimating normal incident radiation for other time periods are made possible using the existing horizontally measured data.

The method proceeds as follows:

$A_{\perp}$, the annual total solar energy received at normal incidence is given by

$$
A_{\perp}=\sum_{\text {year }} I_{D n}
$$

where

$I_{D_{n}}=$ daily insolation received at normal incidence

$\overline{\mathrm{K}}_{\perp}$ is defined as

$$
\overline{\mathrm{K}}_{\perp}=\frac{\mathrm{I}_{\mathrm{Dn}}}{\mathrm{I}_{\mathrm{on}}}
$$

where

$$
I_{\text {on }}=\text { daily insolation received at normal incidence outside atmosphere }
$$
and .

$$
I_{\text {on }}=\frac{24}{\pi} w_{s} \text { r } I_{s c}
$$

where

$$
\begin{aligned}
& \mathbf{w}_{\mathbf{S}}=1 / 2 \text { daylight (radians) } \\
& \mathrm{w}_{S}=\cos ^{-1}(-\tan \mathrm{L} \tan \delta) \\
& \mathrm{L}=\text { latitude } \\
& \delta=\text { declination } \\
& r \text { = ratio solar intensity to mean solar intensity outside the atmosphere } \\
& I_{s c}=428.38 \mathrm{BTU}^{-\mathrm{hr}^{-1}}-\mathrm{ft}^{-2} \\
& .5548\left(\overline{\mathrm{K}}_{\mathrm{H}}\right)^{3}+.9949\left(\mathrm{~K}_{\mathrm{H}}\right)^{2}-.4218 \overline{\mathrm{K}}_{\mathrm{H}}+.0526=. \mathrm{F}\left(\overline{\mathrm{K}}_{\mathrm{H}}\right)
\end{aligned}
$$

$\overline{\mathrm{K}}_{\mathrm{H}}$ can be determined from existing data

$$
\overline{\mathrm{K}}_{\mathrm{H}}=\frac{\mathrm{H} \text { (measured) }}{\mathrm{H}_{\mathrm{O}}}
$$

where

$$
\mathrm{H}_{\mathrm{O}}=\text { daily total solar radiations received on a horizontal surface }
$$

outside the atmosphere and is given by

$$
\mathrm{H}_{\mathrm{O}}=24 / \pi r \mathrm{I}_{\mathrm{sC}}\left[\cos \mathrm{L} \cos \delta \sin \mathrm{w}_{\mathrm{S}}+\mathrm{w}_{\mathrm{S}} \sin \mathrm{L} \sin \delta\right]
$$


since

$$
I_{D_{n}}=I_{\text {on }} \bar{K}_{\perp}=I_{\text {on }} F\left(\bar{K}_{H}\right)=\frac{24}{\pi} w_{s} r I_{s c} F\left(\bar{K}_{H}\right)
$$

then

$$
A_{\perp}=\frac{24}{\pi} I_{s c} \sum_{\text {year }} r w_{S} \cdot F\left(\bar{K}_{H}\right)
$$

The $\sum_{\text {year }}$ can be evaluated in segments, where each segment is made small enough to approximate a straight line. Within this segment $F\left(\bar{K}_{H}\right)=C_{1}$, where $C_{i}$ is a constant that varies from segment to segment and is determined from the polynomial. The contribution to $A_{\perp}$ from any segment becomes

$$
\frac{24}{\pi} I_{s c} \sum_{\text {year }}^{\text {segment }} r w_{s} \cdot C_{i}=\frac{24}{\pi} I_{s c} c_{i} \sum_{\text {year }}^{\text {segment }} r w_{s}
$$

The term " $\sum_{\text {year }} \mathrm{rw}_{s}$ is a weighted count of days occurring in the chosen $\overline{\mathrm{K}}_{\mathrm{H}}$ segment: With this weighted count the contribution of this segment to the quantity $A_{\perp}$ can be determined. Summarizing over all segments yields the total $A_{\perp}$ result.

Figure 8 shows the weighted $\overline{\mathrm{K}}_{\mathrm{H}}$ occurrence frequency for Upton for two different time periods and illustrates the effect of climatic changes upon this weighted sum. Figure 9 shows the long term occurrence frequency of $\overline{\mathrm{K}}_{H}$ for four other locations and shows the variation in this parameter with location along the eastern seaboard.

Using this method for computing $A_{\perp}$ and the results shown in Figure 9 long term average values for $A_{\perp}$ can be determined for these four locations.. Results. are summarized in Table 2 .

Table 2

Locations

Boston, Mass.

New York, N.Y.

Sterling, VA

Charleston, S.C.
Long Term Annual Solar Energy Receiver at Nominal Incidence

$3.51 \times 10^{5} \mathrm{BTU}-\mathrm{ft}^{-2}$-year $\mathrm{y}^{-1}$

3.27

3.63

3.95 
Table 3 shows values of $A_{\perp}$ as computed by William Dickinson and reported in reference 4 .

Table 3

Location

Phoenix, AZ

Albuquerque, NM

Fort Worth, TX

Omaha, NB

Nashville, TN

Blue Hill, MA
Long Term Annual Solar Energy Received at Normal Incidences (ref. 4)

$7.98 \times 10^{5}$ BTU-ft. ${ }^{2}-y r .-1$.

8.19

5.45

5.17

4.17

3.78

Annual normal incident solar radiations received at Upton, N.Y. can also be computed for each year for which good horizontal data is available. Figure 10 presents these results. Data for the $1960^{\prime} \mathrm{s}$ is not computer accessible. A smooth curve has been passed through the data of Figure 10 suggesting long term seasonable changed. During the next decade Upton, N.Y. might anticipate receiving an average of $5.0 \times 10^{5}$ BTU-ft. ${ }^{2}-y r .-1$ solar radiation at normal incidence.

Acknowledgements

The author wishes to acknowledge the invaluable assistance and enthusiastic cooperation which he received from the meterology group under the direction of Dr. Paul Michaels. The computer analysis by J. L. Techler, data reduction, by Robert M. Brown and Paul Vasganian was essentlal to this work.

\section{References}

1. B.Y.H. Lui and R. C. Jordan, A Rational Procedure for Predicting the Long-Term Average Performance of Flat-Plate Solar-Energy Collectors, Solar Energy Vol. 7, No. 2, 1963.

2. Constance M. Nagle, Climatology of Brookhaven National Laboratory 1949 through 1973, report BNL 50466.

3. Constance M. Nagle, Climatology of Brookhaven National Laboratory 1974 through 1977, report BNL 50857.

4. William C. Rickinson, Annual Available Radiations for Fixed and Tracking Collectors, Solar Energy, Vol. 21, No. 3; 1978. 


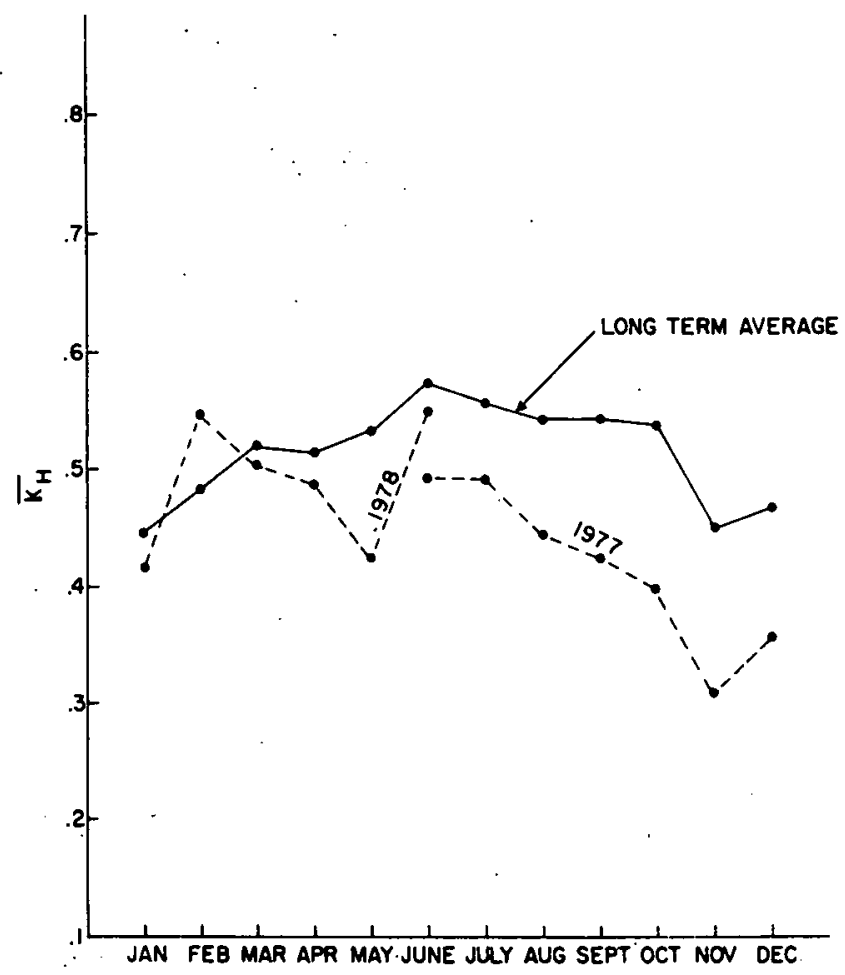

Figure 1. $\overline{\mathrm{K}_{\mathrm{H}}}$, the ratio of daily average radiation measured on a horizontal to that received outside the atmosphere, versus time.

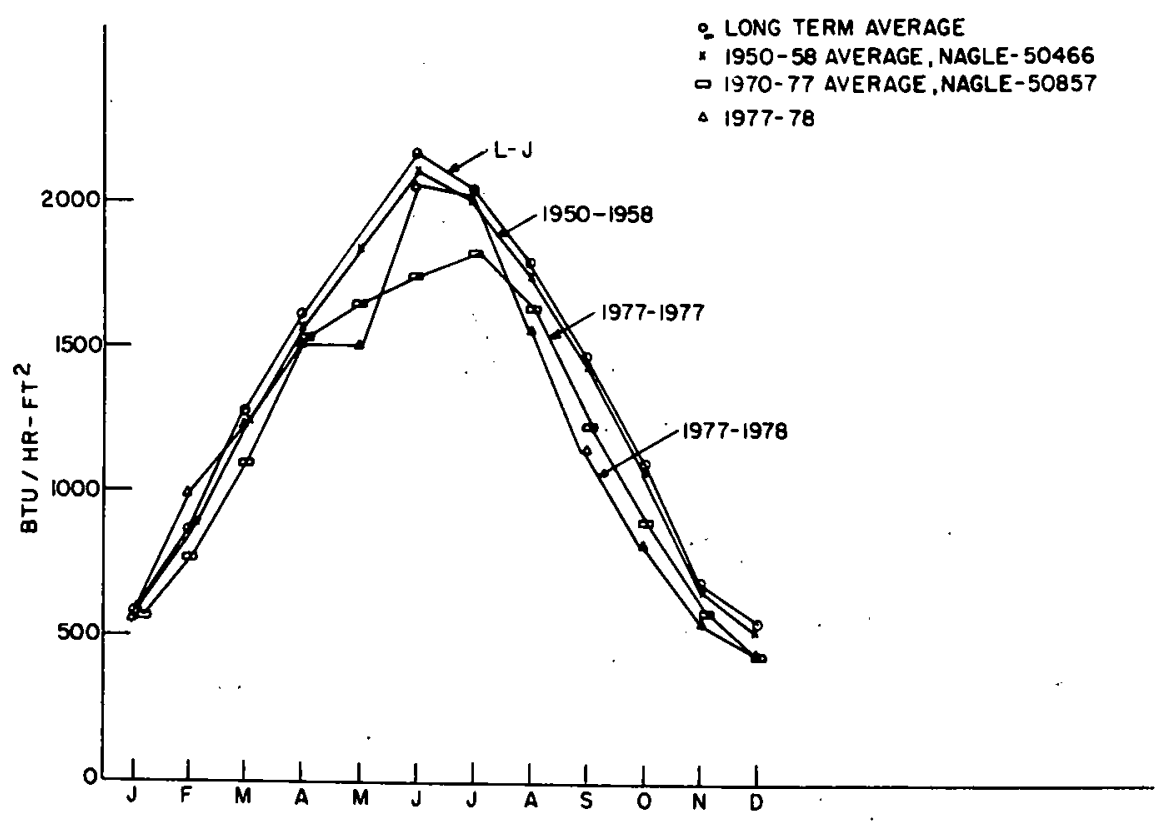

Figure 2. Solar radiation measured on a hor izontal surface at Upton, N.Y. report by varlous authors and time perlods. 


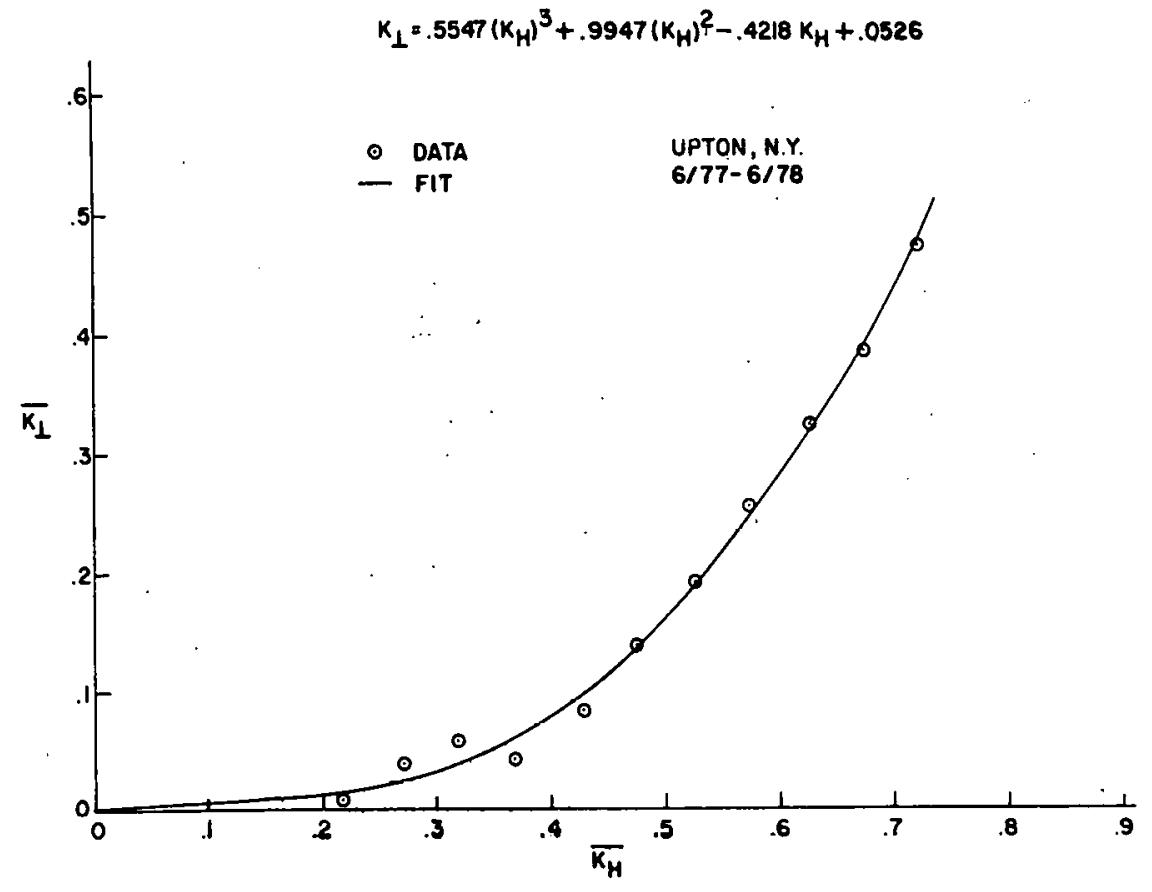

Figure 3a. Measures values of $\overline{\mathrm{K}_{\mathrm{H}}}$ versus $\overline{\mathrm{K}}$ grouped Into bins and averaged for ipton, N.Y. 6/77 through $6 / 78$ with least. squares fit polynomial of 3 rd order.

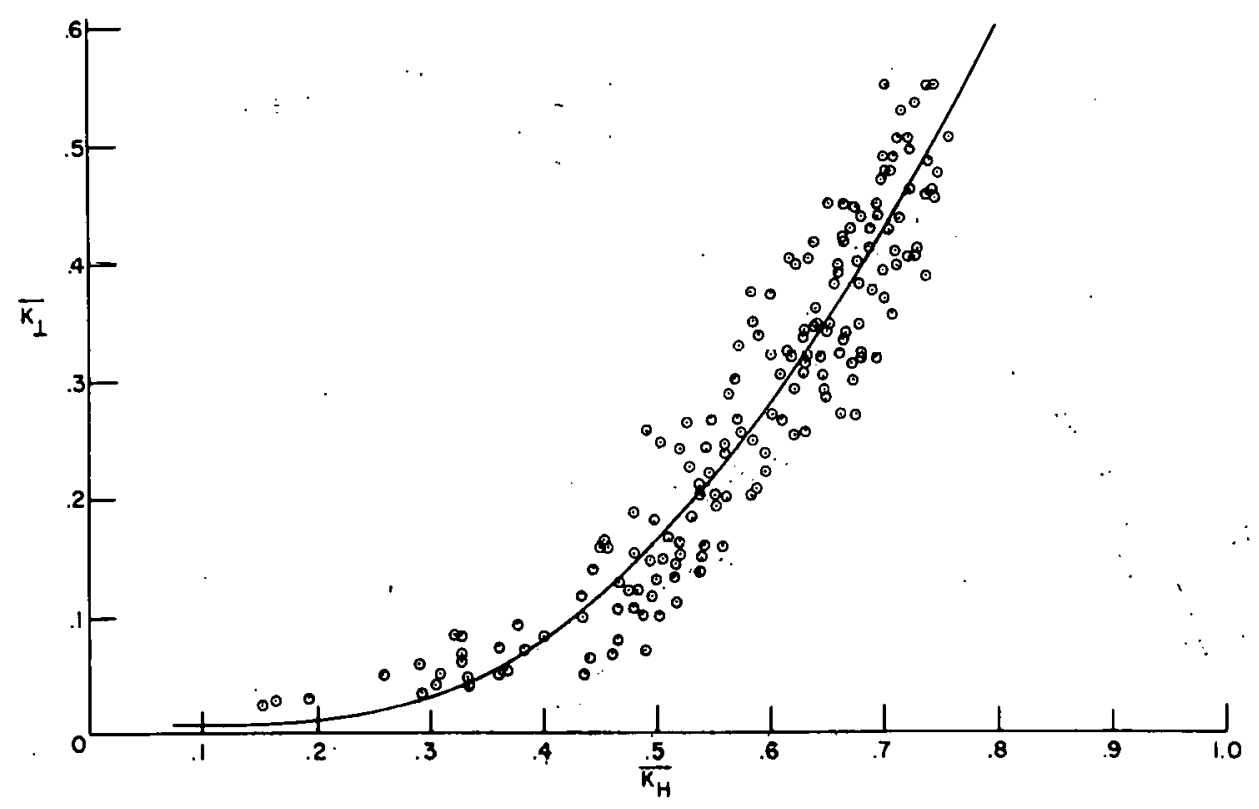

F1gure 3b. Daily values of $\overline{\mathrm{K}_{\mathrm{H}}}$ and $\overline{\mathrm{K}}$ plotted against fit polynomial from Figure 3. 


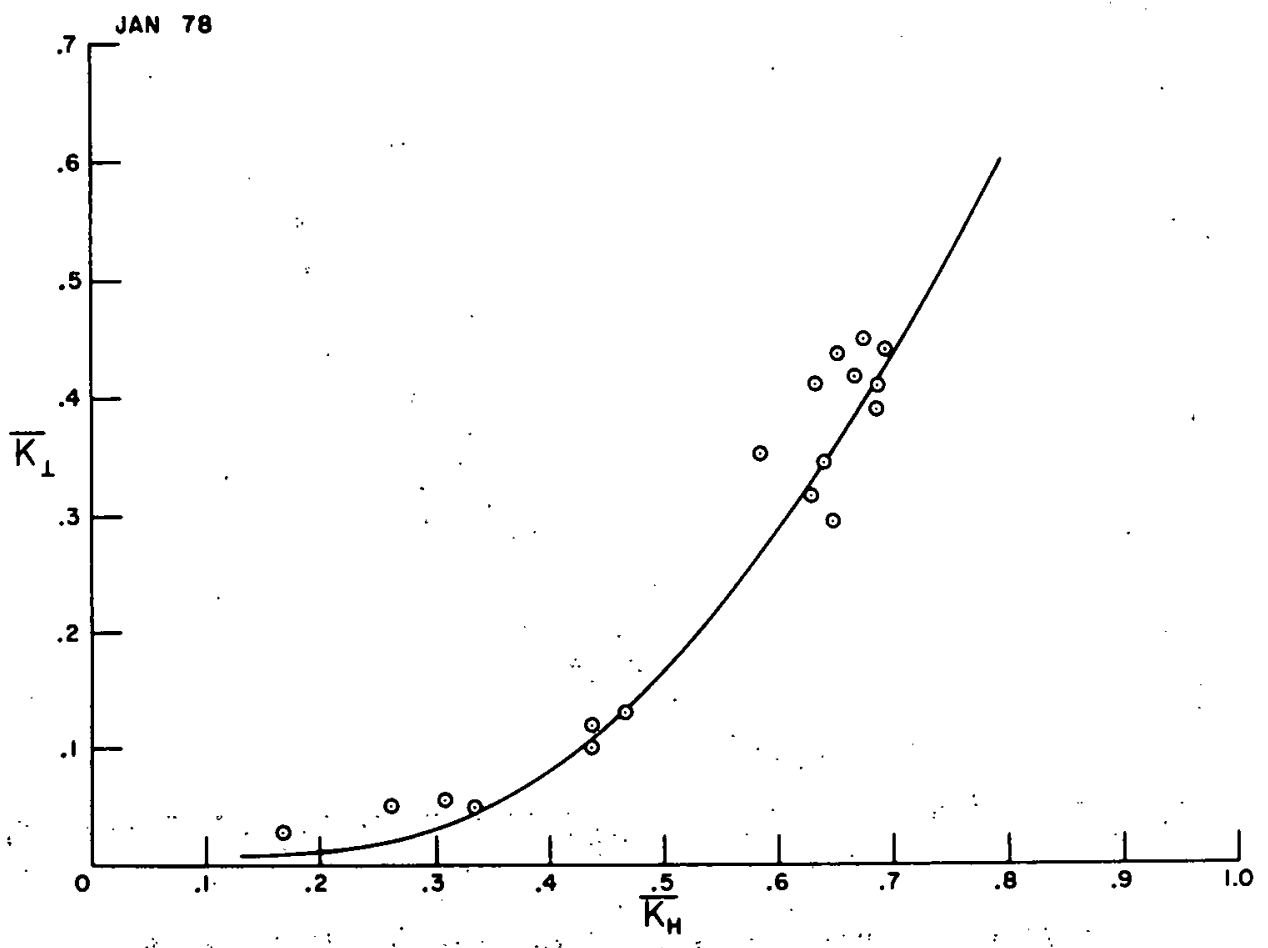

Figure 4. Curve fit versus data from January 1978.

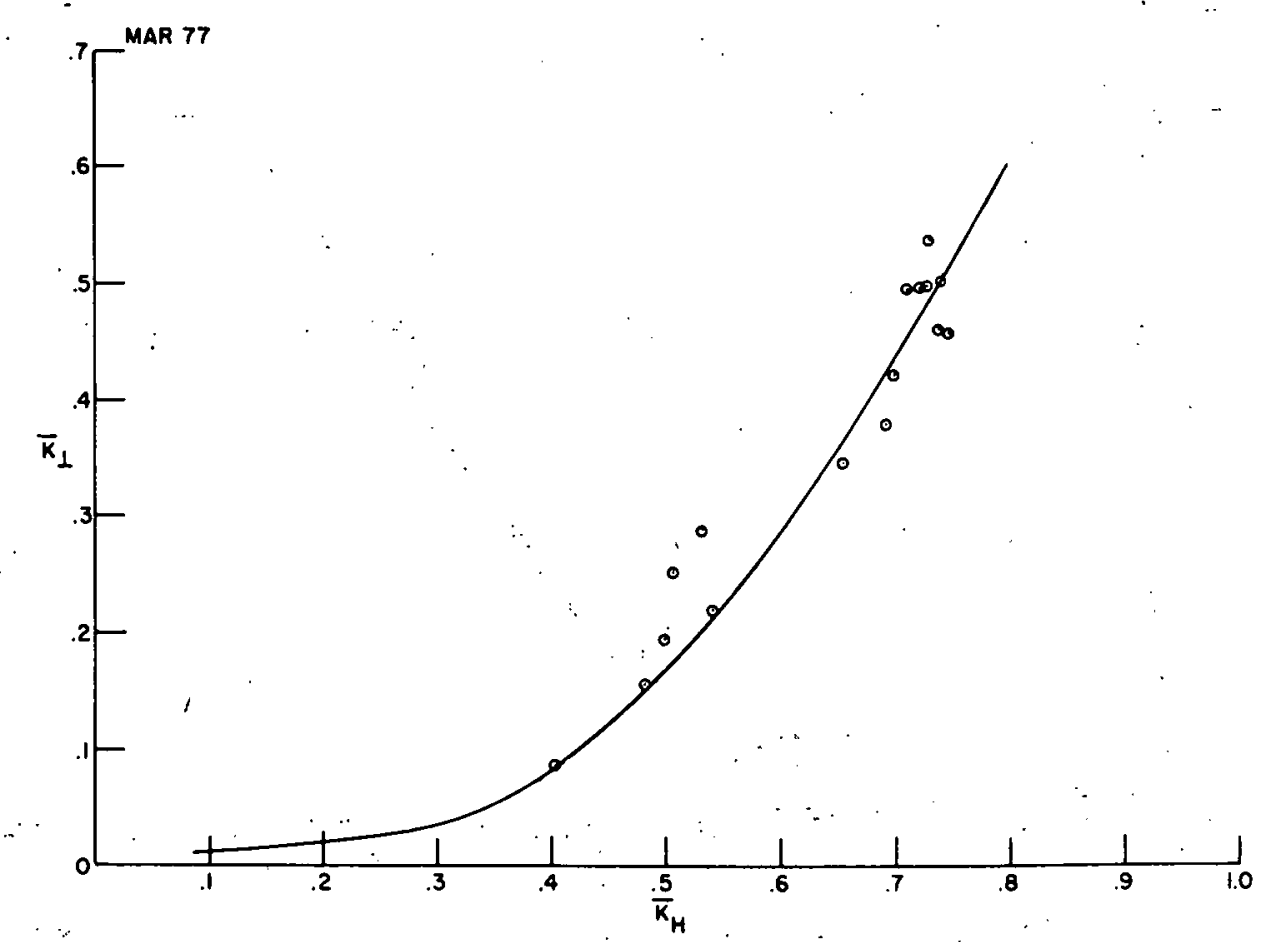

Figure 5. Curve f1t versus data from March 1977. 


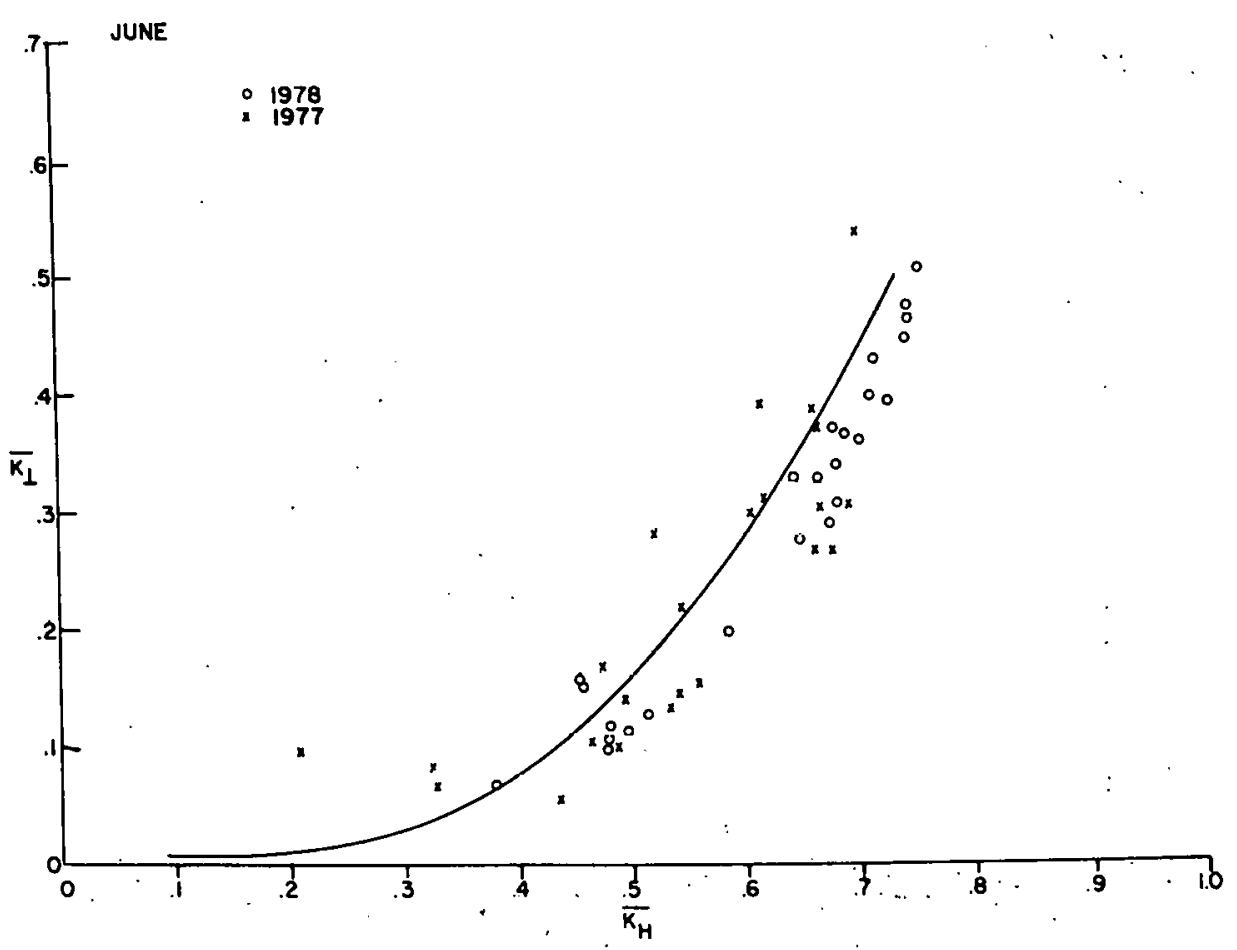

Figure 6. Curve fit versus data from June 1977 and 1978.

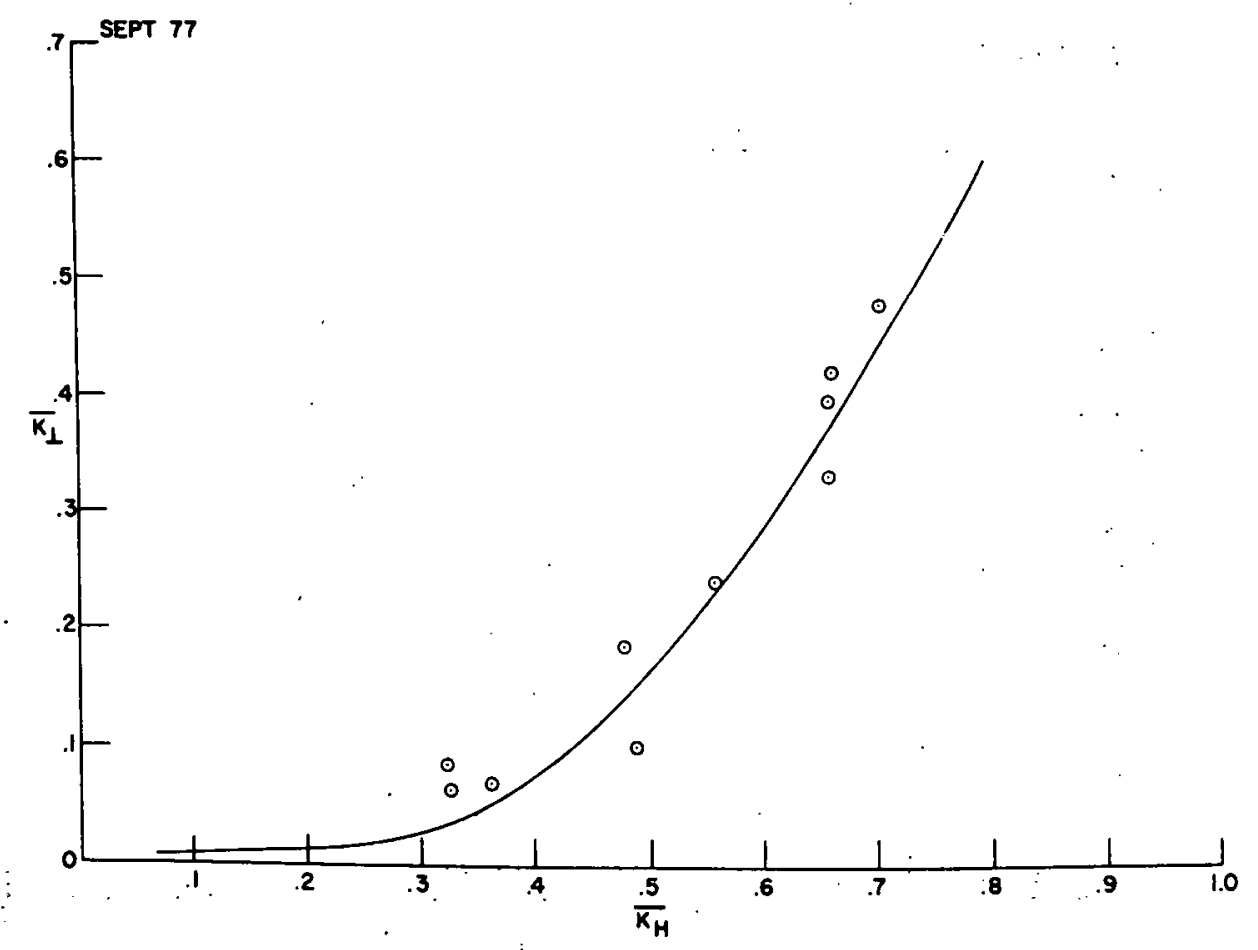

Figure 7. Curve fit versus data from September $1977^{\circ}$ 


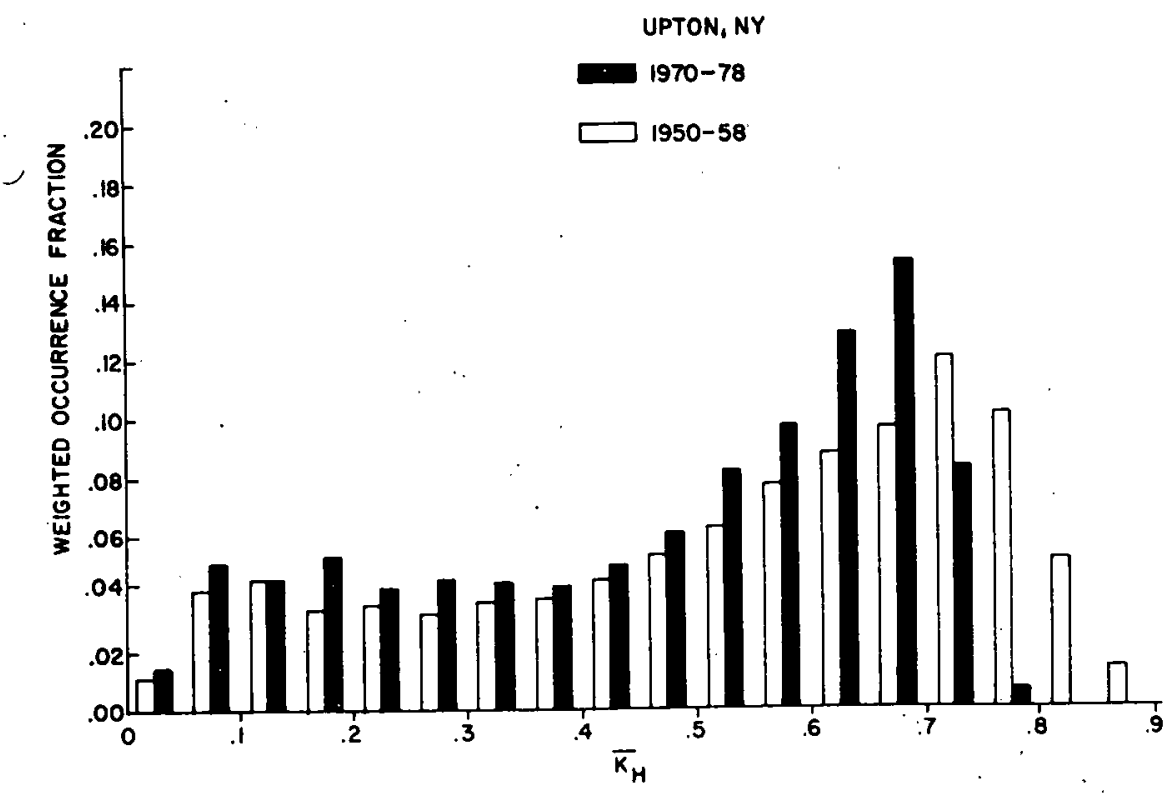

Figure 8. Weighted $\overline{\mathrm{K}_{\mathrm{H}}}$ occurrence frequency for $\dot{\mathrm{U}}$. N.Y. for time period $1950-58$ and $1970-78$.

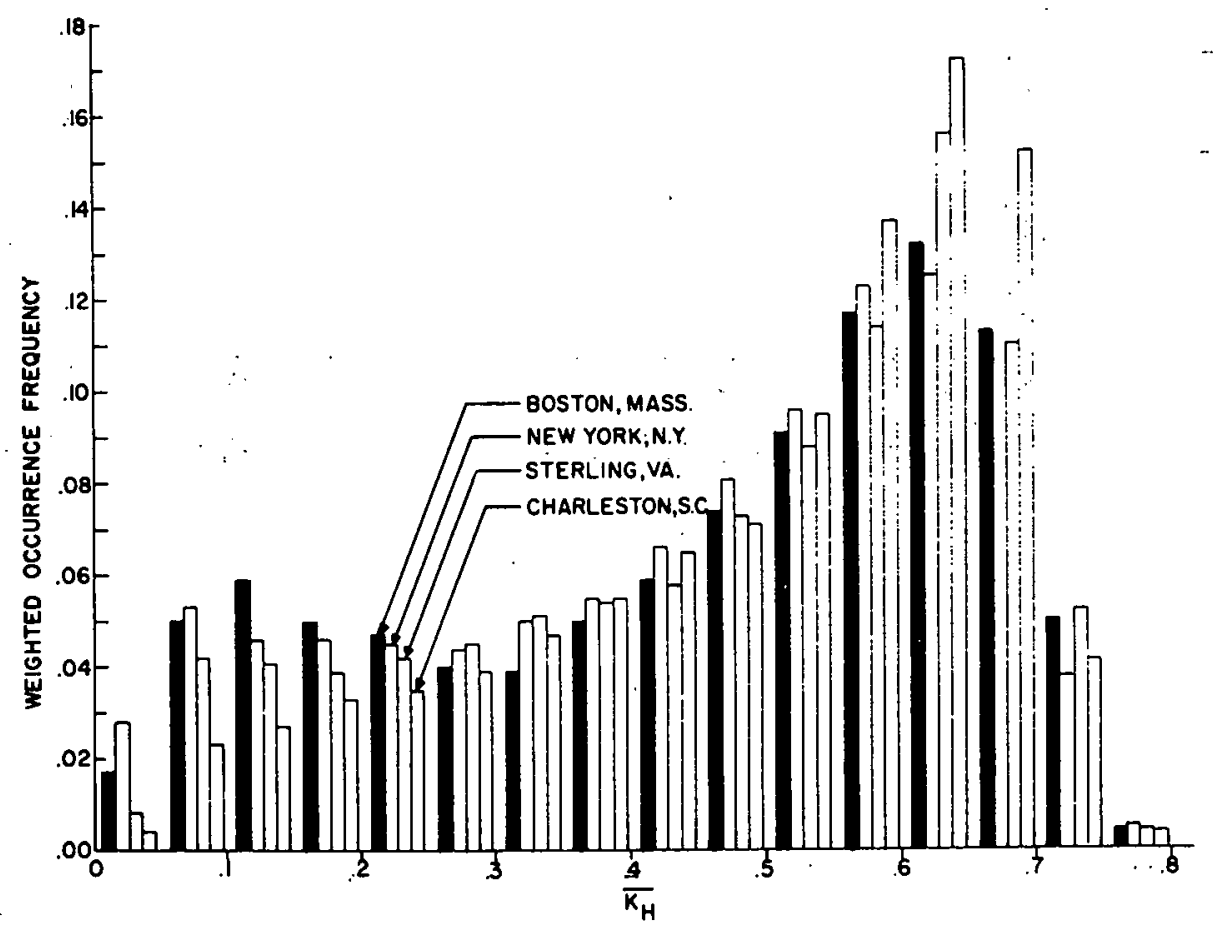

Figure 9. Long term weighted $\overline{\mathrm{K}_{\mathrm{H}}}$ occurrence frequency for Boston, Mass; New York, N.Y.; Sterling, Va.: Charleston, S.C. 
AGS DIV 78-5

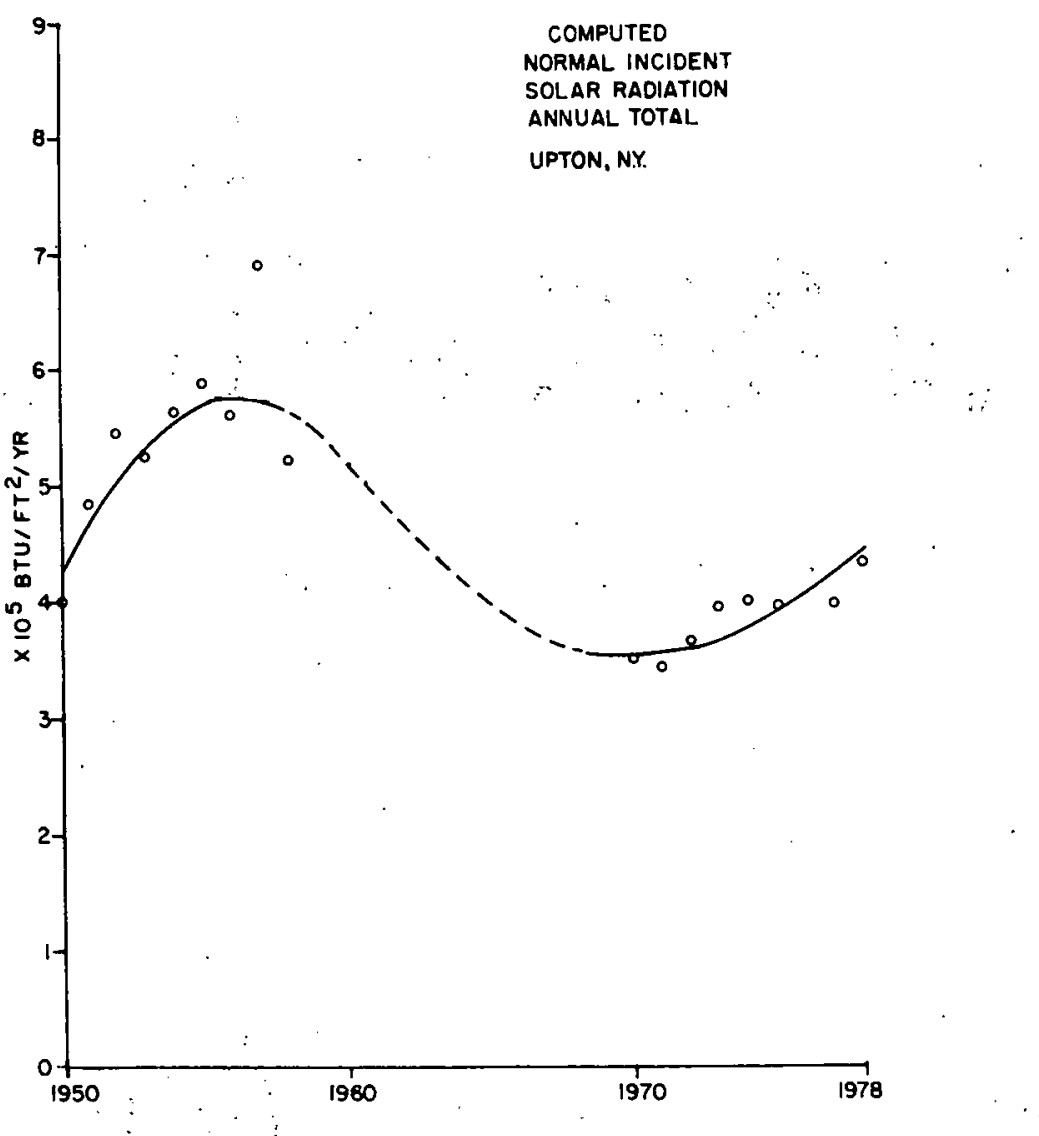

Figure 10. Computed annual normal incident solar radiation received at Upton, N.Y. 
